Impact Factor: 4.845(SJIF) Research Journal Of English (RJOE) Vol-5, Issue-1, 2020

www.rjoe.org.in An International Peer-Reviewed English Journal

ISSN: 2456-2696

Indexed in: International Citation Indexing (ICI), International Scientific Indexing

(ISI), Directory of Research Journal Indexing (DRJI) Google Scholar \& Cosmos.

\title{
AMBIGUITY OF THE TITLE A STUDY OF WOLE SOYINKA'S THE LION AND THE JEWEL
}

\author{
T.Gnanasekaran, \\ Assistant Professor in English, \\ Vidhyaa Giri College of Arts \& Science, \\ Puduvayal, Karaikudi, Tamilnadu
}

\begin{abstract}
Wole Soyinka is a renowned post-colonial author whose works are capable of holding their own standing even when taken out of the African context that the works depict. His play that is the subject of this paper, The Lion and the Jewel, is yet again one such dynamic piece of writing, and the fact that it is a play makes it so all the more multi-dimensional; the stage directions, the props, and the settings add to the exotic elements of the play. What this paper seeks to do is to endeavour to explore the idea behind the title of the play and to match the character to the same. Whether such direct characterizations are valid is something that is further explored, as one finds that a particularly quality that makes humans different from many other creatures is their ability to be multi-faceted. The answer as to who the lion and who the jewel are is not as simple as it seems.
\end{abstract}

Keywords: Wole Soyinka, post-colonial, The Lion and the Jewel, title, drama, play

\section{Introduction}

"A high-voltage literary dynamo, he possesses magnificent power to shock, stimulate, agitate, ignite, activate, enlighten and all the while entertain his audience. He has got what it takes to move men and set them thinking," says Bernth Lindfors in praise of Wole Soyinka in his essay "Wole Soyinka, When Are You Coming Home?" (197). Accolades for Soyinka and his works see no limits as many critics and readers alike are quick to shower him with words of adoration. For the particular play as an object of study, The Lion and the Jewel, there is still more praise and accolades to come.

The Lion and the Jewel is a brilliant sex comedy in which the magnetic field of attraction and repulsion between three characters caught in an amusing African variation of the classic love triangle is presented with absolute clarity. We understand the characters and the situation perfectly, yet Soyinka succeeds in springing some surprises on us which, in retrospect, seem not only extremely well motivated but delightfully inevitable. It is impossible to lose the thread of dramatic discourse for the action is always unambiguous, the dialogue deliciously 
Impact Factor: 4.845(SJIF) Research Journal Of English (RJOE) Vol-5, Issue-1, 2020

www.rioe.org.in An International Peer-Reviewed English Journal

ISSN: 2456-2696

Indexed in: International Citation Indexing (ICI), International Scientific Indexing (ISI), Directory of Research Journal Indexing (DRJI) Google Scholar \& Cosmos.

crisp, and the comic interest constant. Even if Soyinka had written nothing else, this theatrical gem would have won him a reputation as one of Africa's most extravagantly talented playwrights.

What sets him apart from other colonial and post-colonial writers is the way in which his works are never reduced to being pigeon-holed depictions of the African society that Soyinka is a part of. His writing strives to be relevant to the global society at large. His works depict and allude to numerous social issues that transcend borders and cultures. J.K. Kronenfeld opines that Soyinka "exposes self-seeking and inconsistency — beneath various guises - in all the characters" (204). In this particular play, Soyinka never explicitly picks a side in the prevalent war between traditionalism and modernity. He deals with all the characters with a heavy hand and never blatantly favours one over the other. He is successful in presenting an unbiased view that helps the readers to make their own judgements and come to their own conclusions. He makes the readers think beyond the superficial level of the words that he has crafted together and encourages them to dig deeper towards the complex undercurrents of meaning. An aspect of the play that is noteworthy at first glance is its metaphorical title, The Lion and the Jewel. A cursory run through of the play would make any reader come to the conclusion that the lion here is Baroka and the jewel is Sidi. But, as is expected of Soyinka, these associations are not as simple as they seem to be initially The classical motif of deception in the game of sexual warfare and conquest seen here is ingeniously transposed into a metaphor for the continuing relationship of old Africa to new Africa represented here by the "wily old chief" Baroka and the "young, priggish, western-educated suitor" Lakunle (King 341).

Another comparison that can be made is between the two fore grounded women characters of Sidi and Sadiku. However, we find the lines of actual perceptible comparisons to connect quite differently. And this shows the ingenious talent in Soyinka as a playwright.

Lakunle states quite dramatically enough, "For that, what is a jewel to pigs?"(Soyinka 5). This explicitly shows Lakunle calling himself a jewel among the pigs that are the rest of his tribesmen. And what signifies Lakunle's greater claim over the title of the 'jewel' is the fact that he was the first to claim himself to be so. He sees his greatness as a teacher and as the harbinger of modernity to the "race of savages" (5) as sparkles to his metaphorical being as a jewel. He further considers the taunts that are hurled at him-such as being told that a "court jester" (15) might have been a better vocation for him, and even insults that emasculate him such as when Sidi called him "eunuch" (19)-as mere friction which increases his shine. This notion of his is further shown in this line where he states that: "Wise men have been called $\mathrm{mad} /$ Before me and after." (6). He also finds his love for Sidi akin to "the sun" that opens "the chaste leaf in the morning" (7), therefore endeavouring to further glorify himself. The other contender that we have for the role of the 'jewel', and the more obvious one at that, is Sidi. She certainly seems to have the pride necessary to consider herself to be a step above 
Impact Factor: 4.845(SJIF) Research Journal Of English (RJOE) Vol-5, Issue-1, 2020

www.rioe.org.in An International Peer-Reviewed English Journal

ISSN: 2456-2696

Indexed in: International Citation Indexing (ICI), International Scientific Indexing (ISI), Directory of Research Journal Indexing (DRJI) Google Scholar \& Cosmos.

the rest, especially after she sees the city magazine with her photographs printed in it. She claims for her beauty to be "beyond the dreams of a goddess" (11). She considers herself to be even greater that the Bale, Baroka, and she is in no way inconspicuous about vocalizing that thought. And it is this action of hers that makes Baroka set his sights on her, for while his initial approaches towards her might have stemmed from physical attraction, his later ploy of a crafty plan was all in order to possess her and burst her inflated ego. Lakunle's claim of "bush girl you are, bush girl you'll always be" (10) stands true when the "jewel of Ilujinle" (21) decides to surrender herself to the very predator that marred her majestic shine and violated her.

It is her vanity, narcissism and her blinding pride which led to walk heedlessly into Baroka's sly trap, leaving the sharp mental faculties that she had boasted of in the dust. He wins over Sidi in "the show of strength and cleverness" (Kronenfeld 205). Baroka seems to quite obviously the 'lion' of the play. Whether Soyinka actually intended Baroka to be the lion, or a fox as he has called and alluded to numerous times in the play, is a question that deserves to be pondered over. The attention and respect that he commands, though the latter is more out of fear rather than genuine respect, speaks volumes on considering him to be the king of the jungle, the 'lion' of the tribe. Another interesting parallel that one might notice is the family structure of Baroka's harem with that of the pride pack of a lion. A traditional pride consists of a main lion and several lionesses and the lion breeds each one of these lionesses during their heat cycles. This is similar to the way Baroka manages his harem of wives and the heat period in the lionesses can be associated with the period that a particular wife remains a favourite of Baroka and gains his almost undivided attention. Baroka, however is often called to be another sort of animal, a predator nonetheless, as one possessing "the fox's cunning"

(Soyinka 32). This is evidenced by the way Lakunle exposes the underhanded way in which he played the field to his advantage and prevented the railway from running through the forest and prevented the conventional first symbol of modernity and civilization from entering the jungle. Lakunle goes on to further say that Baroka had done this because " $\mathrm{He}$ loves this life too well/to bear to part from it" (24).

The last character that is taken into focus here is Sadiku. Sadiku, Baroka's eldest wife and head of the harem of wives, is a character who initially does not seem to fit anywhere in the two roles of discussion here. However, she comes into the limelight when she gullibly believes all that Baroka tells her about him becoming impotent that she lapses into a frenzy from immense happiness and satisfaction of finally having subdued Baroka's strength.

She declares herself to belong to the "race of mighty lions" who has "scotched" (30) Baroka's father, Okiki, and in the end, destroyed even Baroka's hyper-masculine dignity and 
Impact Factor: 4.845(SJIF) Research Journal Of English (RJOE) Vol-5, Issue-1, 2020

www.rjoe.org.in An International Peer-Reviewed English Journal

ISSN: 2456-2696

Indexed in: International Citation Indexing (ICI), International Scientific Indexing (ISI), Directory of Research Journal Indexing (DRJI) Google Scholar \& Cosmos.

thereby conquered him and his power. Although it is clear here that she is another fox in disguise as she pays no heed to the safekeeping of Baroka's secret and is quick to engage in the joyful revelry of her supposed victory. A lion she may claim to be, but she is definitely a person who has been patiently waiting to pounce upon her prey like a sly fox and is willing to resort to underhanded means to do so. In the last section of the play, we see the cunning fox aspect of her character rear its head again as she is quick to bless Sidi with prayers of fertility, "May the time come soon when you shall be as round-bellied as a full moon in a low sky" (57). This change in sides might be because she supposes that being in the good graces of the new favourite wife might help in softening the impact of her impending punishment from Baroka. The obvious characters fulfilling the roles of the lion and the jewel time and again reiterate the same. Sidi claims herself to be "the twinkle of a jewel" and calls Baroka as "the hind quarters of the lion" (22). Though the latter is meant to be an insult, it still is an association with the lion nonetheless.

What one can draw a conclusion from the events in the play is the fact that regardless of whether or not Lakunle can be called a lustrous jewel or a dull stone, he certainly is not all that different from Baroka. Rather than seeing them as opposing representatives or personifications of traditionalism and modernism, it will do us good to remember it never was Soyinka's intention to present a clear-cut and simple antithesis between the modern and the traditional. He also does not aspire to paint the characters as self-seeking modernism nor responsible traditionalism (Kronenfeld 205). Sidi is yet another character, like certain others in the play, who applies "selective adaptation" (206) to the way she adheres to traditional and modern customs.

She is willing to accept a blend of ideals from both schools of thought as she sees fit and beneficial to herself. "Lakulne is presented by Soyinka with purely mundane motivations" (205), says Kronenefeld. It can be deciphered multiple times in the play that he uses or abuses the "traditional" in accordance with his own needs and situation. Consider his refusal to pay the bride-price: price...

SIDI: But I tell you, Lakunle, I must have The full bride-

LAKUNLE: A savage custom, barbaric, out-dated, Rejected, denounced, accursed,

Excommunicated, archaic, degrading,

Humiliating, unspeakable, redundant

Retrogressive, remarkable, unpalatable. (Soyinka 8)

While Lakunle does bring out every relevant word from "the Shorter Companion Dictionary" (8) to express his disapproval at the custom, it can be seen that his reluctance also arises from the fact that his economic stature simply does not allow him to pay the price. There have been numerous occasions inthe play where he expresses envy at 
Impact Factor: 4.845(SJIF) Research Journal Of English (RJOE) Vol-5, Issue-1, 2020

www.rjoe.org.in An International Peer-Reviewed English Journal

ISSN: 2456-2696

Indexed in: International Citation Indexing (ICI), International Scientific Indexing (ISI), Directory of Research Journal Indexing (DRJI) Google Scholar \& Cosmos.

the way the Baroka lives - "I sometimes wish I led his kind of life" (25), says Lakunle at the thought of Baroka's harem. This clearly shows that he desires to lead Baroka's way of life. Even Lakunle and Baroka's motivations to posses Sidi is because of the same yet different ways they see her as extensions of their pride and self-images (Kronenefeld 207). Lakunle believes that he can potentially mould her in the image of a modern city woman while Baroka's attraction towards her stems from the want to attain something or someone that was coveted by others. What triumphed here is not Baroka's traditionalism over Lakunle's modernism, but rather Baroka's cunning and wily intelligence over Lakunle's naïve simple-mindedness.

\section{Conclusion}

This particular comedy play attempts to see humans as Kronenefeld stated that "in terms of their universal motivations of pride, power and sex, which culture provides various means of satisfying, not in terms of their allegiance to old or new cultural values per se" (208). Bruce King calls Soyinka, "a modern who writes from an African-centred world view without nostalgia for an idealized past, and his attitude is sophisticated, cosmopolitan, and international in awareness, reference, and relevance" (339). This line is a perfect description of his writing and how, especially in The Lion and the Jewel, his witty and satirical metaphors and correlations stand the test of time. This drama presents certain caricatures that serve as a warning to be forever wary of the so-called jewels and lions around us and is also a lesson to be taken against becoming one of these characters.

\section{References:}

- King, Bruce. Wole Soyinka and the Nobel Prize for Literature. The Sewanee Review JSTOR. Web. 1988; 96(2):339-345.

- Kronenfeld JK. The 'Communalistic' African and the 'Individualistic' Westerner: Some Comments on Misleading Generalizations in Western Criticism of Soyinka and Achebe. Research in African Literatures JSTOR. Web. 1975; 6(2):199-225.

- Lindfors, Bernth. Wole Soyinka, When Are You Coming Home? Yale French Studies: Traditional and Contemporary African Literature JSTOR. Web. 26 Mar. 2018. 1976; 53:197-210.

- Soyinka, Wole. The Lion and the Jewel. Wole Soyinka: Collected Plays 2. Oxford: OUP, 1976, 1-58. 